\title{
Succinate dehydrogenase (SDHx) mutations in pituitary tumors: could this be a new role for mitochondrial complex II and/or Krebs cycle defects?
}

\author{
Paraskevi Xekouki and Constantine A Stratakis
}

\begin{abstract}
Section on Endocrinology and Genetics (SEGEN), Program on Developmental Endocrinology and Genetics (PDEGEN), Eunice Kennedy Shriver National Institute of Child Health and Human Development (NICHD), Inter-Institute Pediatric Endocrinology Program, National Institutes of Health (NIH), Building 10, CRC, Room 1-3330, 10 Center Drive, MSC1103, Bethesda, Maryland 20892, USA

(Correspondence should be addressed to C A Stratakis; Email: stratakc@mail.nih.gov)
\end{abstract}

\begin{abstract}
Succinate dehydrogenase (SDH) or mitochondrial complex II is a multimeric enzyme that is bound to the inner membrane of mitochondria and has a dual role as it serves both as a critical step of the tricarboxylic acid or Krebs cycle and as a member of the respiratory chain that transfers electrons directly to the ubiquinone pool. Mutations in SDH subunits have been implicated in the formation of familial paragangliomas (PGLs) and/or pheochromocytomas (PHEOs) and in Carney-Stratakis syndrome. More recently, SDH defects were associated with predisposition to a Cowden disease phenotype, renal, and thyroid cancer. We recently described a kindred with the coexistence of familial PGLs and an aggressive GH-secreting pituitary adenoma, harboring an SDHD mutation. The pituitary tumor showed loss of heterozygosity at the SDHD locus, indicating the possibility that $S D H D$ 's loss was causatively linked to the development of the neoplasm. In total, 29 cases of pituitary adenomas presenting in association with PHEOs and/or extra-adrenal PGLs have been reported in the literature since 1952. Although a number of other genetic defects are possible in these cases, we speculate that the association of PHEOs and/or PGLs with pituitary tumors is a new syndromic association and a novel phenotype for SDH defects.
\end{abstract}

Endocrine-Related Cancer (2012) 19 C33-C40

\section{Introduction}

Succinate dehydrogenase (SDH) or succinate-coenzyme $\mathrm{Q}$ reductase is a multimeric enzyme that is bound to the inner membrane of mitochondria (Oyedotun \& Lemire 2004). It has a dual role as it serves both as a critical step of the tricarboxylic acid (TCA) or Krebs cycle and as a member of oxidative phosphorylation, the respiratory chain that transfers electrons directly to the ubiquinone pool (Kantorovich \& Pacak 2010). It is a highly conserved protein complex that consists of four subunits: two hydrophilic, a flavoprotein (SDHA) and an ironsulfur protein (SDHB) that together form the catalytic core of the enzyme (SDHA serves as the substrate binding site for succinate), and two hydrophobic subunits, SDHC and SDHD, that anchor the holotetramer to the membrane and serve as the ubiquinone site (Oyedotun \& Lemire 2004, Kantorovich \& Pacak 2010).

\section{Syndromes related to SDHx mutations}

The discovery that mutations in genes coding for the subunits $S D H B, S D H C$, and $S D H D$ were responsible for the formation of multiple and possibly coexisting parasympathetic and sympathetic paragangliomas (PGLs) and/or pheochromocytomas (PHEOs) (Baysal et al. 2000, Astuti et al. 2001) made obsolete (Dluhy 2002) at least one part of the axiom that had been proposed by Bravo \& Gifford (1984); the so-called ' 10 rule' had stated that $10 \%$ of PHEOs were bilateral, $10 \%$ malignant, $10 \%$ normotensive, $10 \%$ extra-adrenal, and $10 \%$ genetic origin. Today, we know that as many as $40 \%$ of PHEOs/PGLs may be due to a genetic defect (Raygada et al. 2011); in children and young adults, this may be true in as many as three out of four patients.

In 2007, Stratakis et al. described germline mutations of the $S D H B, S D H C$, and $S D H D$ genes in 
Table 1 Reported cases of coexistence of PHEO/PGL and pituitary adenoma

\begin{tabular}{|c|c|c|c|c|c|}
\hline Report & $\begin{array}{l}\operatorname{Age}^{\mathrm{a}} / \\
\operatorname{sex}\end{array}$ & Case & $\begin{array}{l}\text { Genetic } \\
\text { screening }\end{array}$ & $\begin{array}{l}\text { Family history for } \\
\text { endocrine tumors }\end{array}$ & Comments \\
\hline Iversen (1952) & $44 / \mathrm{M}$ & Acromegaly/PHEO & $-{ }^{\mathrm{b}}$ & NA & \\
\hline Kahn \& Mullon (1964) & $40 / \mathrm{M}$ & Acromegaly/PHEO & $-{ }^{b}$ & NA & \\
\hline $\begin{array}{l}\text { O’Higgins et al. } \\
\quad(1967)\end{array}$ & $21 / F$ & $\begin{array}{l}\text { Acromegaly/PHEO } \\
\text { increased serum calcium } \\
\text { (PHP?) }\end{array}$ & $-{ }^{\mathrm{b}}$ & NA & \\
\hline Steiner et al. (1968) & $41 / \mathrm{M}$ & $\begin{array}{l}\text { Cushing's disease/bilateral } \\
\text { PHEOs/medullary thyroid } \\
\text { cancer }\end{array}$ & $--^{\mathrm{b}}$ & $\begin{array}{l}\text { Positive for MEN for } \\
\text { VI generations }\end{array}$ & \\
\hline Wolf et al. (1972) & $43 / F$ & $\begin{array}{l}\text { Pituitary adenoma } \\
\text { (probably nonfunctioning), } \\
\text { PHEO/PHP, medullary } \\
\text { thyroid cancer }\end{array}$ & $-{ }^{\mathrm{b}}$ & NA & \\
\hline Farhi et al. (1976) & $19 / F$ & $\begin{array}{l}\text { Acromegaly/PGLs/, } \\
\text { parathyroid hyperplasia, } \\
\text { pigmentary abnormalities }\end{array}$ & $--^{b}$ & Negative & \\
\hline $\begin{array}{l}\text { Kadowaki et al. } \\
\text { (1976) }\end{array}$ & $44 / \mathrm{M}$ & Acromegaly/PHEO & $-{ }^{b}$ & NA & \\
\hline $\begin{array}{l}\text { Osamura et al. } \\
\text { (1977) }\end{array}$ & $58 / \mathrm{M}$ & $\begin{array}{l}\text { Acromegaly/PHEO/renal } \\
\text { carcinoma }\end{array}$ & $-{ }^{\mathrm{b}}$ & NA & \\
\hline Manger et al. (1977) & $15 / F$ & Acromegaly/PHEO & $-{ }^{\mathrm{b}}$ & NA & \\
\hline Melicow (1977) & $52 / F$ & $\begin{array}{l}\text { Chromophobe adenoma of } \\
\text { pituitary/papillary carci- } \\
\text { noma of thyroid/PHEO } \\
\text { diagnosed postmortem }\end{array}$ & $-^{b}$ & NA & \\
\hline Janson et al. (1978) & $28 / F$ & $\begin{array}{l}\text { Pituitary adenoma } \\
\text { (probably nonfunctioning) } \\
\text { /bilateral PHEO }\end{array}$ & $-{ }^{\mathrm{b}}$ & $\begin{array}{l}\text { Positive for PHEOs/ } \\
\text { islet cell tumor/ } \\
\text { renal adenoma }\end{array}$ & \\
\hline Alberts et al. (1980) & $36 / F$ & $\begin{array}{l}\text { Pituitary adenoma (?) } \\
\text { /PHEO/islet cell tumor } \\
\text { (gastrinoma), Cushing's } \\
\text { syndrome (adrenal corti- } \\
\text { cal adenoma), parathyr- } \\
\text { oid hyperplasia }\end{array}$ & $-^{\mathrm{b}}$ & NA & \\
\hline $\begin{array}{l}\text { Myers \& Eversman } \\
\text { (1981) }\end{array}$ & $53 / F$ & Acromegaly/PHEO/PHP & $--^{\mathrm{b}}$ & Negative & \\
\hline $\begin{array}{l}\text { Anderson et al. } \\
\quad(1981)\end{array}$ & $53 / F$ & $\begin{array}{l}\text { Acromegaly/PHEO/ } \\
\text { parathyroid hyperplasia } \\
\text { (diagnosed post-mortem) }\end{array}$ & $-^{\mathrm{b}}$ & Negative & \\
\hline $\begin{array}{l}\text { Anderson et al. } \\
\quad(1981)\end{array}$ & $58 / F$ & Acromegaly/PHEO & $-{ }^{\mathrm{b}}$ & Negative & $\begin{array}{l}\text { Hypertension in one } \\
\text { sibling (PHEO?) }\end{array}$ \\
\hline Meyers (1982) & $35 / F$ & Prolactinoma/PHEO & $-{ }^{\mathrm{b}}$ & NA & \\
\hline Roth et al. (1986) & $43 / M$ & $\begin{array}{l}\text { Acromegaly (nodular } \\
\text { somatotroph } \\
\text { hyperplasia)/PHEO }\end{array}$ & $-{ }^{\mathrm{b}}$ & Negative & $\begin{array}{l}\text { Ectopic GHRH } \\
\text { secretion from } \\
\text { PHEO }\end{array}$ \\
\hline Bertrand et al. (1987) & $26 / M$ & $\begin{array}{l}\text { Prolactinoma/PHEO/bilate- } \\
\text { ral medullary thyroid } \\
\text { carcinoma (MTC), } \\
\text { parathyroid adenoma }\end{array}$ & $-{ }^{b}$ & $\begin{array}{l}\text { Father: metastatic } \\
\text { MTC/probably } \\
\text { PHEO }\end{array}$ & \\
\hline Teh et al. (1996) & $41 / \mathrm{M}$ & $\begin{array}{l}\text { Acromegaly/PHEO/abdom- } \\
\text { inal PGL }\end{array}$ & $R E T:(-)$ & NA & \\
\hline Baughan et al. (2001) & $43 / \mathrm{M}$ & $\begin{array}{l}\text { Acromegaly/PHEO/heman- } \\
\text { gioma/lipoma/parotid } \\
\text { adenoma }\end{array}$ & $R E T:(-)$ & Negative & $\begin{array}{l}\text { Maybe ectopic } \\
\text { GHRH secretion } \\
\text { (not measured) }\end{array}$ \\
\hline Dünser et al. (2002) & $56 / \mathrm{M}$ & $\begin{array}{l}\text { Pituitary adenoma } \\
\text { (probably not secreting) } \\
\text { /PHEO }\end{array}$ & Not performed & NA & \\
\hline Sleilati et al. (2002) & $57 / F$ & Acromegaly/PHEO & $R E T$ : negative & Negative & $\begin{array}{c}\text { Negative for GHRH } \\
\text { ectopic secretion }\end{array}$ \\
\hline
\end{tabular}




\begin{tabular}{|c|c|c|c|c|c|}
\hline Report & $\begin{array}{l}\operatorname{Age}^{\mathrm{a}} / \\
\operatorname{sex}\end{array}$ & Case & $\begin{array}{l}\text { Genetic } \\
\text { screening }\end{array}$ & $\begin{array}{l}\text { Family history for } \\
\text { endocrine tumors }\end{array}$ & Comments \\
\hline $\begin{array}{l}\text { Breckenridge et al. } \\
\text { (2003) }\end{array}$ & $59 / \mathrm{M}$ & $\begin{array}{l}\text { Pituitary adenoma (non- } \\
\text { secreting)/PHEO }\end{array}$ & Not performed & Negative & \\
\hline $\begin{array}{l}\text { López-Jiménez et al. } \\
\text { (2008) }\end{array}$ & $60 / \mathrm{M}$ & $\begin{array}{l}\text { Prolactinoma/nonsecreting } \\
\text { PGL }\end{array}$ & $S D H C(+)$ & $\begin{array}{l}\text { 2/4 children are } \\
\text { carriers of the } \\
\text { same mutation. } \\
\text { Parents' history: } \\
\text { negative }\end{array}$ & \\
\hline Saito et al. (2010) & $40 / \mathrm{M}$ & Acromegaly/MTC & $R E T(+)$ & $\begin{array}{l}\text { Mother PHEO/MTC } \\
\quad \operatorname{RET}(+)\end{array}$ & \\
\hline Zhang et al. (2011) & $45 / \mathrm{M}$ & Acromegaly/PGLs & Not performed & $\begin{array}{l}\text { Father and sister } \\
\text { neck PGLs }\end{array}$ & \\
\hline Heinlen et al. (2011) & $60 / \mathrm{M}$ & $\begin{array}{l}\text { PHEO/nonsecreting } \\
\text { pituitary adenoma/MTC }\end{array}$ & $R E T(+)$ & NA & \\
\hline Sisson et al. (2011) & $29 / \mathrm{M}$ & $\begin{array}{l}\text { Bilateral PHEOs/ } \\
\text { acromegaly/PTC }\end{array}$ & Not performed & Negative & \\
\hline Xekouki et al. (2012) & $37 / \mathrm{M}$ & $\begin{array}{l}\text { Acromegaly/bilateral } \\
\text { PHEOS/PGLs }\end{array}$ & $\begin{array}{l}S D H D(+) \mathrm{LOH} \text { of } \\
S D H D \text { locus in } \\
\text { pituitary } \\
\text { adenoma }\end{array}$ & $\begin{array}{l}\text { Sister, paternal } \\
\text { uncle: neck PGLs } \\
\text { (same mutation) }\end{array}$ & \\
\hline
\end{tabular}

NA, not available; PHEO, pheochromocytoma; PGL, paraganglioma; PTC, papillary thyroid cancer; MTC, medullary thyroid cancer; PHP, primary hyperparathyroidism; MEN, multiple endocrine neoplasia; $\mathrm{M}$, male; $\mathrm{F}$, female.

The age at first visit.

${ }^{\mathrm{b}}$ DNA testing was not available at that time.

patients with PGLs and gastrointestinal stromal tumors (GISTs), negative for mutations in PDGFRA or KIT genes (McWhinney et al. 2007). GISTs from these patients showed allelic losses of the $S D H B$ and $S D H C$ chromosomal loci pointing to a tumor-suppressor function of SDH subunits (SDHx) in these neoplasms. This was the first time that a germline mitochondrial oxidation defect was linked to predisposition for development of a sarcoma. More recently, $S D H x$ mutations (or functional variants) were associated with predisposition to a Cowden disease-like phenotype that consisted of breast, endometrial, thyroid, kidney, colorectal cancers, dermatological features such as oral and skin papillomas, and neurological manifestations such as autism and Lhermitte Duclos disease (Ni et al. 2008), as well as with renal and thyroid cancer (Neumann et al. 2004, Vanharanta et al. 2004).

\section{Pituitary adenomas and PHEOs/PGLs as part of multiple endocrine neoplasia syndromes}

Pituitary adenomas represent one of the components of multiple endocrine neoplasia type 1 (MEN1) due to mutations in MEN1 gene, the other components being primary hyperparathyroidism and pancreatic tumors. Adenomas and adenomatous hyperplasia of the thyroid and adrenal glands may also occur in patients with MEN1 (Thakker 2010).

PHEOs/PGLs, primary hyperparathyroidism, and medullary thyroid cancer are the main tumors that occur in multiple endocrine neoplasia type 2 (MEN2), with particular marfanoid habitus in MEN2B subtype. The genetic causes are gain-of-function mutations in RET proto-oncogene (Wohllk et al. 2010).

There have been some reports in the literature of MEN1 where PHEOs (unilaterally or bilaterally) were identified in patients with proven MEN1 mutations. However, the prevalence of PHEOs in MEN1 appears to be $<0.1 \%$ (Gatta-Cherifi et al. 2012).

We just described a kindred with the coexistence of familial PGLs and an aggressive GH-secreting pituitary adenoma, harboring a $S D H D$ mutation (Xekouki et al. 2012). The pituitary tumor showed loss of heterozygosity ( $\mathrm{LOH})$ at the $S D H D$ locus, indicating the possibility that this gene's loss was causatively linked to the development of the neoplasm (Xekouki et al. 2012). Until this report, coexistence of a pituitary adenoma and PHEOs/PGL was not recognized as a distinct entity. However, since 1952, we have identified 29 cases in the literature of pituitary adenomas copresenting with PHEO and/or extraadrenal PGLs (Table 1); in most reports, the coexistence of these two tumors was described as a unexpected 'coincidence'. Unfortunately, no genetic 
testing was available until the 1990 's, so we can only hypothesize that some of the early cases presented in Table 1 could represent cases of MEN syndromes or may be due to $S D H x$ mutations. The most recent cases described by Sisson et al. (2011) and Zhang et al. (2011) have a lot of similarities with our case and most probably are cases of familial PGLs.

The only other reported patient with a pituitary tumor and neck PGLs due to an SDHC splice site mutation is the one reported by López-Jiménez et al. (2008). However, the prolactinoma could not be tested for $\mathrm{LOH}$, so we can only speculate that this particular mutation may have contributed to the patient's pituitary tumor formation.

\section{Proposed mechanisms}

The above data and the number of cases in Table 1 indicate that the association of certain pituitary tumors and SDHx mutations may be a real one, adding this neoplasm to the ever increasing list of lesions associated with SDH deficiency. How could this be
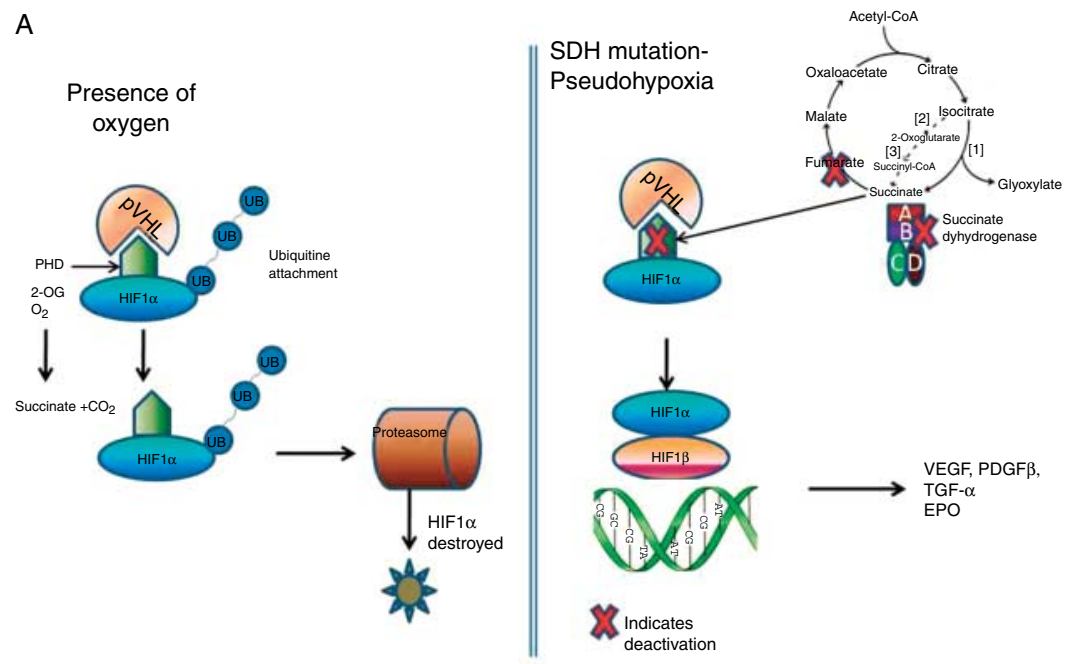

B

Cytoplasm

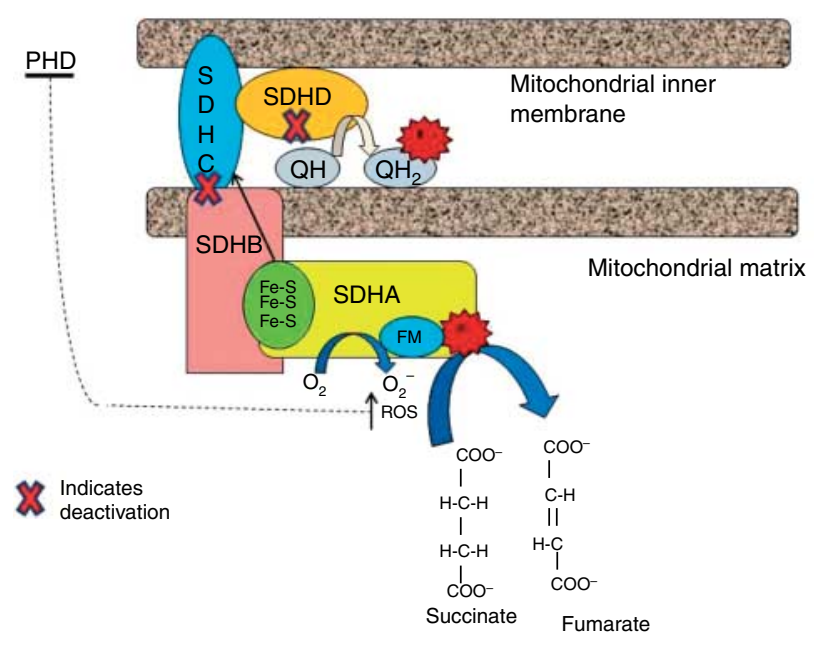

Figure 1 (a) Mechanisms of pseudohypoxia in inherited PHEO and/or PGLs: inactivation of SDH leads to the abnormal stabilization of HIFs in normoxia that escape degradation and translocate to the nucleus, where they dimerise with HIF1 $\beta$ and promote transcription of genes that enhance tumorigenesis, e.g. VEGF, PDGF- $\beta$ (2-OG, a-ketoglutarate; HIFs, hypoxia-inducible factors; PHD, prolyl hydroxylases; SDH, succinate dehydrogenase; VHL, Von Hippel-Lindau). (b) Oxidation of succinate to fumarate transfers the electrons through a sequence of steps from the flavin moiety in SdhA to a set of three iron-sulfur clusters in SdhB, to the ubiquinone binding site in SdhC and SdhD. When complex II is disrupted due to mutations in SdhB, SdhC, or SdhD, the electron transfer is impaired promoting superoxide generation through the autoxidation of the reduced flavin group by $\mathrm{O}_{2}$ in the matrix (FM, flavin moiety; Fe-S, iron-sulfur clusters; $\mathrm{e}^{-}$, electron transfer; $\mathrm{QH}$, ubiquinone; $\mathrm{QH}_{2}$, ubiquinol). 
molecularly plausible? Several mechanisms have been proposed to explain how the dysfunction of SDHx can lead to the formation of PHEOs/PGLs. The first model is 'pseudohypoxia' and accumulation of reactive oxygen species (ROS). In normoxic conditions, a family of oxygen-dependent enzymes known as prolyl hydroxylases (PHD) 1, 2, and 3 (also known as Egln2, $E g \ln 1$, and $E g \ln 3$ ) hydroxylate the three $\alpha$ subunits of hypoxia inducible factor $\alpha$ (HIF $1 \alpha, \operatorname{HIF} 2 \alpha$, and HIF $3 \alpha$ ). The hydroxylated HIF $\alpha$ s are then targeted by von Hippel-Lindau (VHL) protein, an E3 ubiquitin ligase, polyubiquitinated and degraded in the proteasome. Only hydroxylated HIF $\alpha$ s can be targeted by VHL for degradation. However, if PHDs are inhibited by the accumulated succinate (such as when SDHx are mutated), HIF $\alpha$ s are not hydroxylated, escape degradation, and translocate to the nucleus, where they dimerise with HIF1 $\beta$ and bind to specific promoter elements of target genes including critical angiogenic factors such as vascular endothelial growth factor (VEGF), enzymes involved in glucose metabolism, and cell survival, and possibly a number of others (Raimundo et al. 2011; Fig. 1a). Activation of the HIF pathway and the resulting angiogenic and glycolytic response in SDHx-mutated tumors was first reported by Selak et al. (2005) and has been replicated in many studies. Certainly, the 'pseudohypoxia' hypothesis is not new: Otto Warburg in the 1920s described a striking rate of glycolysis and lactate production in tumor cells, in the presence of normal oxygen concentrations (Warburg 1956). Warburg proposed that this phenomenon might be related to a defect in mitochondrial respiration, or some other mechanism that allows the tumor cell to function as hypoxic under normoxic conditions. It took over 80 years for the 'Warburg effect' to be confirmed, and today, it is the basis for the use of functional imaging strategies such as the $\left[{ }^{18} \mathrm{~F}\right]$ deoxyglucose-positron emission tomography $\left({ }^{18} \mathrm{~F}-\mathrm{FDG} \mathrm{PET}\right)$ for the diagnosis of PHEO/PGLs (Bayley \& Devilee 2010). The generation of ROS due to the SDH/complex II deficiency in the presence of SDHx mutations has also been implicated in tumor formation, although ROS are usually a 'by-product' of other elements of the electron transport chain, particularly complex I (NADH-ubiquinone oxidoreductase) and III (ubiquinone-cytochrome $c$ oxidoreductase). ROS might promote tumor formation in SDH-deficient cells by inhibiting PHD activity similar to succinate accumulation (Bardella et al. 2011; Fig. 1b). The accumulation of succinate in SDH-deficient tumors may also inhibit other components of $\alpha$-ketoglutarate-dependent enzymes besides PHDs. It was recently demonstrated

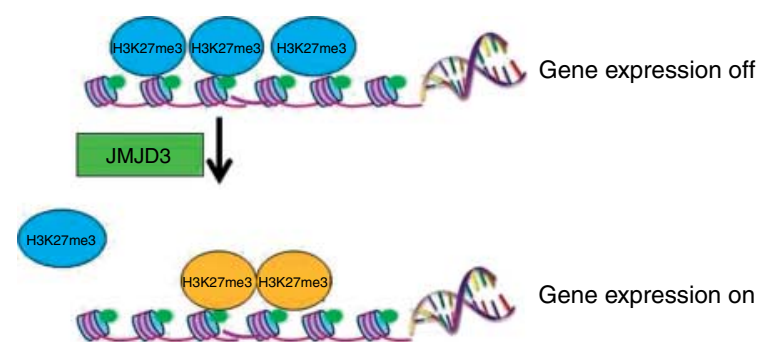

Figure 2 Methylation of histones like trimethylated lysine 27 on histone $\mathrm{H} 3$ (H3K27me3) controls transcription by allowing chromosomal regions to alternate between 'on' and 'off'. Jumonji domain-containing 3 (JMJD3) belongs to a family of enzymes that uses a Jumonji $\mathrm{C}(\mathrm{JmjC})$ domain to catalyze demethylation on lysines. In cells with inactivated $S D H B$, increased methylation of histone $\mathrm{H} 3$ can be reversed by overexpression of the JMJD3, indicating that histone demethylases may be involved in the formation of paragangliomas (and related tumors).

that loss of SDHB subunit in a yeast model led to succinate accumulation, which could cause the inhibition of two different $\alpha$-ketoglutarate-dependent dioxygenases: the Jlp1, involved in sulfur metabolism, and the histone demethylases Jhd1, which belongs to the JmjC-domain-containing histone demethylase (JHDM) enzymes. It was also demonstrated that JMJD2D, the corresponding human JHDM, was inhibited by succinate accumulation (Smith et al. 2007). Inhibition of the histone demethylases could certainly lead to tumor formation by a variety of epigenetic changes (Bardella et al. 2011). Indeed, increased methylation of histone $\mathrm{H} 3$ that can be reversed by overexpression of the JMJD3 histone demethylase was recently reported in $S D H B$-silenced cells (Fig. 2). ChIP analysis revealed that the core promoter of IGFBP7, which encodes a secreted protein upregulated after the loss of SDHB, showed decreased occupancy by trimethylated lysine 27 on histone H3 (H3K27me3) in the absence of SDHB. Moreover, type I chief cells, which are considered the neoplastic component of PGLs, were shown as the major methylated histone-immunoreactive component of the paraganglial carotid tumors tested (Cervera et al. 2009). Overall, these findings demonstrated that succinate could act not only as a messenger between mitochondria to cytosol but also as a signal between mitochondria to nucleus, for the regulation of chromatin structure and gene expression.

\section{Conclusions}

Could all of this be happening in the pituitary as well? The mechanism by which SDHx germline mutations might contribute to pituitary tumor formation is still 
elusive. In our studies, we showed increased expression of HIF1 $\alpha$ in the $S D H D$-mutant tumor cells compared with normal pituitary and GH-secreting adenoma cells without SDH defects (Xekouki et al. 2012). Clearly, further research is needed to prove SDHx mutation involvement in predisposition to pituitary tumors; however, the clinical cases and the preliminary laboratory data make this enzyme a likely candidate for yet another molecular mechanism through which pituitary tumors may form.

\section{Declaration of interest}

The authors declare that there is no conflict of interest that could be perceived as prejudicing the impartiality of the review reported.

\section{Funding}

This work was entirely supported by the Intramural Program of the Eunice Kennedy Shriver National Institute of Child Health and Human Development (NICHD).

\section{References}

Alberts WM, McMeekin JO \& George JM 1980 Mixed multiple endocrine neoplasia syndromes. Journal of the American Medical Association 244 1236-1237. (doi:10.1001/jama.1980.03310110046029)

Anderson RJ, Lufkin EG, Sizemore GW, Carney JA, Sheps SG \& Silliman YE 1981 Acromegaly and pituitary adenoma with phaeochromocytoma: a variant of multiple endocrine neoplasia. Clinical Endocrinology 14 605-612. (doi:10.1111/j.1365-2265.1981.tb02971.x)

Astuti D, Latif F, Dallol A, Dahia PL, Douglas F, George E, Sköldberg F, Husebye ES, Eng C \& Maher ER 2001 Gene mutations in the succinate dehydrogenase subunit SDHB cause susceptibility to familial pheochromocytoma and to familial paraganglioma. American Journal of Human Genetics 69 49-54. (doi:10.1086/321282)

Bardella C, Pollard PJ \& Tomlinson I 2011 SDH mutations in cancer. Biochimica et Biophysica Acta 1807 1432-1443. (doi:10.1016/j.bbabio.2011.07.003)

Baughan J, de Gara C \& Morrish D 2001 A rare association between acromegaly and pheochromocytoma. American Journal of Surgery 182 185-187. (doi:10.1016/S00029610(01)00678-X)

Bayley JP \& Devilee P 2010 Warburg tumours and the mechanisms of mitochondrial tumour suppressor genes. Barking up the right tree? Current Opinion in Genetics \& Development 20 324-329. (doi:10.1016/j.gde.2010. 02.008)

Baysal BE, Ferrell RE, Willett-Brozick JE, Lawrence EC, Myssiorek D, Bosch A, van der Mey A, Taschner PE, Rubinstein WS, Myers EN et al. 2000 Mutations in
SDHD, a mitochondrial complex II gene, in hereditary paraganglioma. Science 287 848-851. (doi:10.1126/ science.287.5454.848)

Bertrand JH, Ritz P, Reznik Y, Grollier G, Potier JC, Evrad C \& Mahoudeau JA 1987 Sipple's syndrome associated with a large prolactinoma. Clinical Endocrinology 27 607-614. (doi:10.1111/j.1365-2265.1987.tb01191.x)

Bravo EL \& Gifford RW Jr 1984 Current concepts.

Pheochromocytoma: diagnosis, localization and management. New England Journal of Medicine 311 1298-1303. (doi:10.1056/NEJM198411153112007)

Breckenridge SM, Hamrahian AH, Faiman C, Suh J, Prayson R \& Mayberg M 2003 Coexistence of a pituitary macroadenoma and pheochromocytoma - a case report and review of the literature. Pituitary 6 221-225. (doi:10.1023/B:PITU.0000023429.89644.7b)

Cervera AM, Bayley JP, Devilee P \& McCreath KJ 2009 Inhibition of succinate dehydrogenase dysregulates histone modification in mammalian cells. Molecular Cancer 8 89. (doi:10.1186/1476-4598-8-89)

Dluhy RG 2002 Pheochromocytoma - death of an axiom. New England Journal of Medicine 346 1486-1488. (doi:10.1056/NEJM200205093461911)

Dünser MW, Mayr AJ, Gasser R, Rieger M, Friesenecker B \& Hasibeder WR 2002 Cardiac failure and multiple organ dysfunction syndrome in a patient with endocrine adenomatosis. Acta Anaesthesiologica Scandinavica $\mathbf{4 6}$ 1161-1164. (doi:10.1034/j.1399-6576.2002.460918.x)

Farhi F, Dikman SH, Lawson W, Cobin RH \& Zak FG 1976 Paragangliomatosis associated with multiple endocrine adenomas. Archives of Pathology \& Laboratory Medicine 100 495-498.

Gatta-Cherifi B, Chabre O, Murat A, Niccoli P, CardotBauters C, Rohmer V, Young J, Delemer B, Du Boullay H, Verger MF et al. 2012 Adrenal involvement in MEN1. Analysis of 715 cases from the Groupe d'étude des Tumeurs Endocrines database. European Journal of Endocrinology 166 269-279. (doi:10.1530/EJE-11-0679)

Heinlen JE, Buethe DD, Culkin DJ \& Slobodov G 2011 Multiple endocrine neoplasia 2a presenting with pheochromocytoma and pituitary macroadenoma. ISRN Oncology 2011 732452. (doi:10.5402/2011/732452)

Iversen K 1952 Acromegaly associated with phaeochromocytoma. Acta Medica Scandinavica $\mathbf{1 4 2}$ 1-5. (doi:10.1111/j.0954-6820.1952.tb13837.x)

Janson KL, Roberts JA \& Varela M 1978 Multiple endocrine adenomatosis: in support of the common origin theories. Journal of Urology 119 161-165.

Kadowaki S, Baba Y, Kakita T, Yamamoto H, Fukase M, Goto Y, Seino Y, Kato Y, Matsukara S \& Imura H 1976 A case of acromegaly associated with pheochromocytoma [in Japanese]. Saishin-lgaku 31 1402-1409.

Kahn MT \& Mullon DA 1964 Pheochromocytoma without hypertension, report of a patient with acromegaly. Journal of the American Medical Association 188 74-75. (doi:10.1001/jama.1964.03060270080022) 
Kantorovich V \& Pacak K 2010 Pheochromocytoma and paraganglioma. Progress in Brain Research 182 343-373. (doi:10.1016/S0079-6123(10)82015-1)

López-Jiménez E, de Campos JM, Kusak EM, Landa I, Leskelä S, Montero-Conde C, Leandro-García LJ, Vallejo LA, Madrigal B, Rodríguez-Antona C et al. 2008 SDHC mutation in an elderly patient without familial antecedents. Clinical Endocrinology 69 906-910. (doi:10.1111/j.1365-2265.2008.03368.x)

Manger WM \& Gifford RW Jr 1977 In Pheochromocytoma, pp 284-286. New York, NY, USA: Springer-Verlag.

McWhinney SR, Pasini B, Stratakis CA \& International Carney Triad and Carney-Stratakis Syndrome Consortium 2007 Familial gastrointestinal stromal tumors and germ-line mutations. New England Journal of Medicine 357 1054-1056. (doi:10.1056/NEJMc071191)

Melicow MM 1977 One hundred cases of pheochromocytoma (107 tumors) at the Columbia-Presbyterian Medical Center, 1926-1976: a clinicopathological analysis. Cancer 40 1987-2004. (doi:10.1002/10970142(197711)40:5 < 1987::AID-CNCR2820400502>3. $0 . \mathrm{CO} ; 2-\mathrm{R})$

Meyers DH 1982 Association of phaeochromocytoma and prolactinoma. Medical Journal of Australia 1 13-14.

Myers JH \& Eversman JJ 1981 Acromegaly, hyperparathyroidism, and pheochromocytoma in the same patient. A multiple endocrine disorder. Archives of Internal Medicine 141 1521-1522. (doi:10.1001/archinte.1981. 00340120129027)

Neumann HP, Pawlu C, Peczkowska M, Bausch B, McWhinney SR \& Muresan M 2004 Distinct clinical features of paraganglioma syndromes associated with SDHB and SDHD gene mutations. Journal of the American Medical Association 292 943-951. (doi:10.1001/jama.292.8.943)

Ni Y, Zbuk KM, Sadler T, Patocs A, Lobo G, Edelman E, Platzer P, Orloff MS, Waite KA \& Eng C 2008 Germline mutations and variants in the succinate dehydrogenase genes in Cowden and Cowden-like syndromes. American Journal of Human Genetics 83 261-268. (doi:10.1016/j. ajhg.2008.07.011)

O'Higgins NJ, Cullen MJ \& Heffernan AG 1967 A case of acromegaly and phaeochromocytoma. Journal of the Irish Medical Association 60 213-216.

Osamura Y, Watanabe K, Nomoto Y, Sasaki H \& Katsuoka Y 1977 Acromegaly, pheochromocytoma, adrenal cortical adenoma and Grawitz tumor in a patient. Presented at the Ninth Meeting on the Functioning Tumours, Tokyo, October 1977.

Oyedotun KS \& Lemire BD 2004 The quaternary structure of the Saccharomyces cerevisiae succinate dehydrogenase. Homology modeling, cofactor docking, and molecular dynamics simulation studies. Journal of Biological Chemistry 279 9424-9431. (doi:10.1074/jbc. M311876200)
Raimundo N, Baysal BE \& Shadel GS 2011 Revisiting the TCA cycle: signaling to tumor formation. Trends in Molecular Medicine 17 641-649. (doi:10.1016/j.molmed. 2011.06.001)

Raygada M, Pasini B \& Stratakis CA 2011 Hereditary paragangliomas. Advances in Oto-Rhino-Laryngology 70 99-106. (doi:10.1159/000322484)

Roth KA, Wilson DM, Eberwine J, Dorin RI, Kovacs K, Bensch KG \& Hoffman AR 1986 Acromegaly and pheochromocytoma: a multiple endocrine syndrome caused by a plurihormonal adrenal medullary tumor. Journal of Clinical Endocrinology and Metabolism 63 1421-1426. (doi:10.1210/jcem-63-6-1421)

Saito T, Miura D, Taguchi M, Takeshita A, Miyakawa M \& Takeuchi Y 2010 Coincidence of multiple endocrine neoplasia type 2A with acromegaly. American Journal of Medical Sciences 340 329-331. (doi:10.1097/MAJ. 0b013e3181e73fba)

Selak MA, Armour SM, MacKenzie ED, Boulahbel H, Watson DG, Mansfield KD, Pan Y, Simon MC, Thompson CB \& Gottlieb E 2005 Succinate links TCA cycle dysfunction to oncogenesis by inhibiting HIF- $\alpha$ prolyl hydroxylase. Cancer Cell 7 77-85. (doi:10.1016/j. ccr.2004.11.022)

Sisson J, Giordano TJ \& Avram AM 2011 Three endocrine neoplasms: an unusual combination of pheochromocytoma, pituitary adenoma and papillary thyroid carcinoma. Thyroid 22 430-436. (doi:10.1089/thy.2011. 0345)

Sleilati GG, Kovacs KT \& Honasoge M 2002 Acromegaly and pheochromocytoma: report of a rare coexistence. Endocrine Practice 8 54-60.

Smith EH, Janknecht R \& Maher LJ III 2007

Succinate inhibition of $\alpha$-ketoglutarate-dependent enzymes in a yeast model of paraganglioma. Human Molecular Genetics 16 3136-3148. (doi:10.1093/hmg/ ddm275)

Steiner AL, Goodman AD \& Powers SR 1968 Study of a kindred with pheochromocytoma, medullary thyroid carcinoma, hyperparathyroidism and Cushing's disease: multiple endocrine neoplasia, type 2. Medicine 47 371-409. (doi:10.1097/00005792-196809000-00001)

Teh BT, Hansen J, Svensson PJ \& Hartley L 1996 Bilateral recurrent phaeochromocytoma associated with a growth hormone-secreting pituitary tumour. British Journal of Surgery 83 1132. (doi:10.1002/bjs. 1800830832)

Thakker RV 2010 Multiple endocrine neoplasia type 1 (MEN1). Best Practice \& Research. Clinical Endocrinology \& Metabolism 24 355-370. (doi:10.1016/j. beem.2010.07.003)

Vanharanta S, Buchta M, McWhinney SR, Virta SK, Peçzkowska M, Morrison CD, Lehtonen R, Januszewicz A, Järvinen H, Juhola M et al. 2004 Early-onset renal cell carcinoma as a novel 
extraparaganglial component of SDHB-associated heritable paraganglioma. American Journal of Human Genetics 74 153-159. (doi:10.1086/381054)

Warburg O 1956 On the origin of cancer cells. Science $\mathbf{1 2 3}$ 309-314. (doi:10.1126/science.123.3191.309)

Wohllk N, Schweizer H, Erlic Z, Schmid KW, Walz MK, Raue F \& Neumann HP 2010 Multiple endocrine neoplasia type 2. Best Practice \& Research. Clinical Endocrinology \& Metabolism 24 371-387. (doi:10.1016/ j.beem.2010.02.001)

Wolf LM, Duduisson M, Schrub JC, Metayer J \& Laumonier R 1972 Sipple's syndrome associated with pituitary and parathyroid adenomas. Annales d'Endocrinologie 33 455-463.

Xekouki P, Pacak K, Almeida M, Wassif CA, Rustin P, Nesterova M, de la Luz Sierra M, Matro J, Ball E,
Azevedo M et al. 2012 Succinate dehydrogenase (SDH) D subunit (SDHD) inactivation in a growth-hormoneproducing pituitary tumor: a new association for SDH? Journal of Clinical Endocrinology and Metabolism 97 E357-E366. (doi:10.1210/jc.2011-1179)

Zhang C, Ma G, Liu X, Zhang H, Deng H, Nowell J \& Miao Q 2011 Primary cardiac pheochromocytoma with multiple endocrine neoplasia. Journal of Cancer Research and Clinical Oncology 137 1289-1291. (doi:10.1007/s00432-011-0985-1)

Received in final form 6 August 2012

Accepted 13 August 2012 Made available online as an Accepted Preprint 13 August 2012 